\title{
Technological and Therapeutic Advances in Advanced Small Cell Lung Cancer
}

\author{
Caroline Lum ${ }^{1}$ and Muhammad Alamgeer ${ }^{1,2, *}$ \\ 1 Department of Medical Oncology, Monash Health and Monash University, Clayton, VIC 3168, Australia; \\ caroline.lum@monashhealth.org \\ 2 Centre for Cancer Research, Hudson Institute of Medical Research, Monash University, Clayton, \\ VIC 3168, Australia \\ * Correspondence: muhammad.alamgeer@monash.edu; Tel.: +61-3-8572-2392
}

Received: 15 September 2019; Accepted: 10 October 2019; Published: 15 October 2019

check for updates

\begin{abstract}
Small cell lung cancer (SCLC) accounts for approximately 10-15\% of all lung cancers. The prognosis is poor with median survival in the advanced stage remaining at around 12 months. Despite applying every known therapeutic approach, no major breakthrough has improved the overall survival in the last 30 years. Historically, experiments performed on conventional cell lines may have limitations of not accurately reflecting the complex biological and genomic heterogeneity of this disease. However, additional knowledge gained from recently developed genetically engineered mouse models (GEMMs) and patient derived xenografts (PDXs) have made encouraging inroads. Whole genome sequencing (WGS) data reveals a high mutational burden and a number of genetic alterations but low frequency of targetable mutations. Despite several failures, considerable therapeutic opportunities have recently emerged. Potentially promising therapies include those targeting DNA damage repair, stem cell/renewal and drug resistant mechanisms. Modest success has also been achieved with immune checkpoint inhibitors while therapeutic exploration of various other components of the immune system is underway. However, the complex heterogeneities reflect the need for accurate bio-markers to translate novel discoveries into clinical benefit. Additionally, the molecular mechanisms that differentiate chemo-sensitive from chemo-refractory disease remain unknown. Obtaining reliable tumour samples by utilising novel techniques such as endobronchial ultrasound guided needle aspiration or adopting to liquid biopsies are becoming popular. This review will focus on recent technological and therapeutic advancements to surmount this recalcitrant disease.
\end{abstract}

Keywords: small cell lung cancer; targeted therapies; immunotherapies; bio-markers

\section{Introduction}

Small cell lung cancer (SCLC) remains a devastating disease, characterised by an aggressive course with early metastasis. Standard first line therapy for extensive stage (ES-SCLC) disease remains platinum-based doublet chemotherapy [1], with response rates (RR) in this setting in the order of $70 \%$ [1]. Inevitable progression eventually follows, with a median survival in ES-SCLC remaining at around 12 months [2]. In a minority of the patients, however, relapse occurs within three months; in these cases, the disease is defined as chemorefractory. Although topotecan has been approved as monotherapy for relapsed SCLC, its low RR and short median survival time have been disappointing [3]. In addition, not only have multiple trials of several cytotoxic agents, dose intensification, as well as novel targeted therapies failed to improve the outcomes over the last three decades [4,5], no specific agents to re-sensitise the tumour cells to chemotherapy could be formulated. In response, the focus of drug development has shifted more towards biological or biomarker directed therapies. The major challenge is to develop efficient models to investigate 
biomarkers in the settings of inter- and intra- tumoural heterogeneity. Current therapeutic focus can be broadly grouped into five major categories: Development and regulatory pathways, DNA damage and repair (DDR), cell cycle inhibitors, epigenetics and immune therapies. This review will focus on these developments as well progress in strategies to distillate effective bio-markers.

\section{Genomics and Pathways in SCLC}

Genomic instability and complex genomic rearrangements are the hallmark of SCLC. High levels of genetic alterations and mutation frequency were found at rates only second to those of melanoma $[6,7]$. WGS data reveals evidence for $\sim 90 \%$ biallelic loss of TP53 and RB1 [6,7]. Some tumours with wild type $R B 1$ have shown to exhibit chromothripsis, where alternative mechanisms of $R B 1$ deregulation, such as overexpression/amplification of cyclin D1 (CCD1) and/or inactivation of cyclin dependent kinase inhibitor 2A (CDKN2A), have been identified [6,8]. Further comprehensive genomic profiling uncovered alterations at both copy number and mutational levels in several key genes involved in cell cycle regulation (CDK4/6), receptor kinase signaling (KIT, FGFR, IGFR), transcriptional regulation (CREBBP, MYCL1, MYCN, MYC), apoptosis (SOX2, BCL2) and Notch signaling/neuroendocrine differentiation $(\mathrm{NOTCH}, A S C L 1)[6,9]$. Further sequencing on patient samples revealed high mutational burden (a feature associated with exposure to carcinogens in tobacco) [10], but unlike non-small cell lung cancer (NSCLC), potentially targetable oncogenic driver mutations have not so far been tracked down in SCLC [11]. Although 'classic and variant' subtypes, based on morphological and biochemical characteristics of SCLC cell lines, were described almost three decades ago [12], it was only in the last five years that a variety of molecular subtypes have emerged [13,14]. Recent profiling studies involving both primary human and mouse tumours supported various models of distinct SCLC molecular subtypes defined by relative expression of key transcription regulators including ASCL1) (achaete-scute homolog 1), NeuroD1 (neurogenic differentiation factor 1), YAP1 (yes-associated protein 1), and POU2F3 (POU domain class 2 homeobox 3) [13]. Subsequently, multiple independent research teams have collaborated together to propose a consistent nomenclature for these subtypes as SCLC-A, SCLC-N, SCLC-Y, and SCLC-P [13] and also hypothesised that these biologically distinct subtypes may also have distinct therapeutic targets (Figure 1).

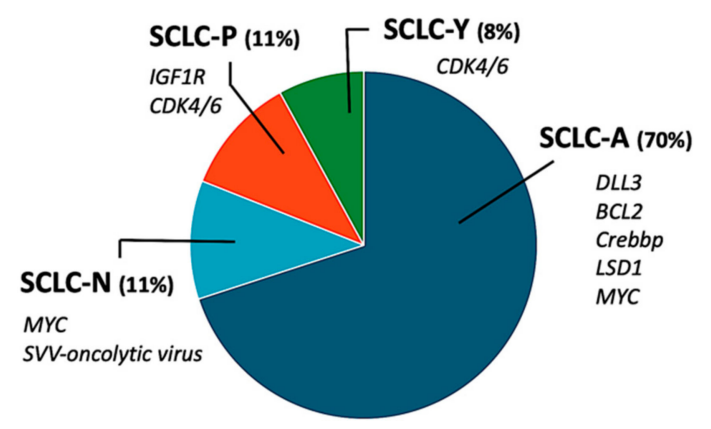

Figure 1. Proposed nomenclature describing small cell lung cancer (SCLC) molecular subtypes. Last letter signifies the most strongly associated transcription factor associated with that particular SCLC subtype. A= (Achaete-scute homologue 1 (ASCL1; also known as ASH1); N= neurogenic differentiation factor 1 (NeuroD1); P = POU class 2 homeobox 3 (POU2F3) and $\mathrm{Y}=$ yes-associated protein 1 (YAP1). Presumed potential targets according to subtypes are illustrated in italics below each subtype. (Proportion of each subtype is approximated based on the combined data from multiple studies involving both cell lines and human tissues).

The intricate genetic features that differentiate chemosensitive from chemorefractory disease currently remain unknown. Unavailability of longitudinal samples to investigate tumour evolution and mechanisms of acquired chemoresistance has been a major reason for this gap in knowledge. In a gene expression profiling study using SCLC cell lines, McColl et al. showed that the rare RB1 WT subtype expressed YAPI (currently classified as SCLC-Y) and was chemo-resistant, while INSM1 
(insulinoma-associated protein 1) expressing subtype (SCLC-A and SCLC-N) was chemosensitive [14]. Further information was gained from a small study involving serial circulating tumour cells (CTCs), where copy number aberrations (CNAs) data pointed towards distinct profiles in patients with chemorefractory and chemosensitive SCLC [15]. The study also implied that the genetic alterations associated with inherent drug resistance may be different to acquired drug resistance [15]. Larger studies with suitable samples are required to confirm these findings. So far several attempts to target traditional platinum resistance mechanisms have been unsuccessful, while others such as targeting DNA repair system are being explored [16].

\section{SCLC and Genomic Heterogeneity}

Genomic heterogeneity is now recognised as a major barrier to the success of conventional therapies in the treatment of cancers [17]. The advent of multi-region sequencing has led to the identification of a previously unknown degree of genomic complexity in solid tumours [18]. However, the landmark findings from analysing multiple tumour sites from a relatively small number of cases, reveal the complexities of genomic evolution and have major implications for the understanding of tumour initiation and progression [19]. Furthermore, they illustrate that analysing multiple tumour sites can reveal the complexities of genomic evolution and heterogeneity that cannot be resolved by single-site sequencing of large cohorts [17]. Though the intratumoural and intertumoural heterogeneity was demonstrated in SCLC cell surface antigens almost three decades ago [20], subclonal architecture of SCLC and its clonal evolution during treatment has not been well delineated, possibly due to lack of multi-site and serial tumour samples. Recent sequencing studies using serial circulating tumour DNA (ctDNA) samples underpinned the genomic landscape of SCLC. A study using serial liquid biopsies from 22 SCLC patients showed post treatment enrichment of mutations associated with chemo-resistance (DNA repair and Notch pathway mutations) using target deep sequencing of 430 cancer genes [21]. The only study to use multi-region sequencing had only one patient with SCLC, revealing that the primary lesion was genomically distinct from the metastatic site and there was heterogeneity in immune related markers [22]. In animal models, Sage et al. showed plasticity in Notch signalling and phenotypic switch from a neuroendocrine to non-neuroendocrine subtype, suggesting the evolution of various subpopulations of SCLC cells and their functional interactions [23].

\section{Targeting Developmental and Regulatory Pathways}

\subsection{Notch Signaling}

Notch signaling is involved in cell fate/neuroendocrine differentiation and plays a pivotal role in the development of SCLC [24]. Delta-like ligand 3 (DLL3), an inhibitory ligand for the Notch receptor, has emerged as an attractive therapeutic target in approximately one third of SCLC, where it is highly expressed $[25,26]$. An antibody drug conjugate (ADC) rovalptizumab tesirine (Rova-T), targeted at DLL3, showed promising pre-clinical and early clinical activity in DLL3 high expressing SCLC [26,27]. In the subsequent phase 2 TRINITY study evaluating Rova-T in patients with DLL3 expressing SCLC who had received at least two prior lines of therapy, overall response rates (ORR) of $16 \%$, with median overall survival (OS) of 5.6 months was reported [28]. Disappointingly, the phase 3 TAHOE study, investigating Rova-T compared to topotecan in the second line was halted early due to poor interim results. Rova-T combination with immune check point inhibitors (ICI) nivolumab and ipilimumab in patients with DLL3 expressing ES-SCLC, in the second line and beyond, showed safety concerns and further optimisation of schedule and dosing was recommended [29]. Disappointingly, the phase 3 MERU study of Rova-T maintenance following first line platinum-based chemotherapy (NCT03033511) was terminated recently due to lack of survival benefit at a pre-planned interim analysis. As a result, further development of this compound was discontinued. 
Two novel approaches in targeting DLL3 are Bi-specific T-cell engagers (BiTE®s; AMGEN $囚$ Science Thousand Oaks, CA, USA) and chimeric antigen receptor (CAR) T cell therapy. In these forms of immunotherapy, cytotoxic T cells are directed at DLL3 expressing SCLC with the aim of selective destruction [30,31]. A phase 1 trial of AMG757, an anti-DLL3 BiTEß molecule, initially in patients with relapsed SCLC and later in patients with at least SD following first line chemotherapy (NCT03319940) is in progress. AMG119 is an adoptive cellular immunotherapy, consisting of patients' derived CAR $\mathrm{T}$ cells that target DLL3. It has shown potent killing of DLL3 expressing SCLC cells in vitro and is currently undergoing evaluation in a phase 1 trial in SCLC patients who progressed after at least one line of therapy (NCT03392064).

\subsection{Hedgehog Pathway}

The Hedgehog pathway $(\mathrm{HH})$, plays a key role in stem cell differentiation and neuroendocrine fate and has been found to be activated in SCLC $[32,33]$. Unlike some other malignancies (basal cell carcinoma, medulloblastoma, and rhabdomyosarcoma), mutations in $\mathrm{HH}$ pathway genes are not typically seen in SCLC; however, upregulation of the HH pathway components has been widely reported [32,34]. Preclinical studies have shown that deletion of Smoothened (SMO); a transmembrane protein inhibited in the absence of a $\mathrm{HH}$ ligand, leads to inactivation of the $\mathrm{HH}$ pathway $[35,36]$. Subsequently, there has been an interest in the development of SMO inhibitors to target SCLC.

A phase 1 study of sonidegib (LDE225), a selective SMO antagonist, combined with cisplatin and etoposide investigated the safety in ES-SCLC. At the maximum tolerated dose (MTD) of $800 \mathrm{mg}$, 11 of 15 patients had a partial response (PR), and one patient with SOX2 amplification continued to have SD after 27 months of maintenance therapy [33]. A similar compound, vismodegib, was studied by Bellani et al. Three treatment arms investigated in 152 patients with newly diagnosed ES-SCLC: Cisplatin and etoposide; cisplatin, etoposide, and vismodegib; cisplatin, etoposide, and cixutumumab (this latter agent targeting insulin like growth factor 1). No statistically significant difference in the progression free survival (PFS), overall survival (OS) or response rate (RR) was observed [35]. Taladegib, also an antagonist of HH/SMO, was evaluated in a phase 1/2 trial in the first line setting of ES-SCLC, in combination with carboplatin and etoposide chemotherapy. The reported ORR was $53.8 \%$ [37]. These disappointing results have led to the discontinuation of further clinical development of $\mathrm{HH}$ inhibitors in SCLC.

\subsection{Receptor Tyrosine Kinase Targeting}

Tyrosine kinase inhibitors (TKIs) in general, have failed in SCLC [4,5]. Recently, anlotinib, a multiple receptor tyrosine kinases inhibitor, targeting vascular endothelial growth factor (VEGF) receptor type two and three, the platelet-derived growth factor $b$ (PDGFR-b), and the stem cell-factor receptor (c-Kit) [38], has shown some efficacy. After establishing safety in a phase I study [39], anlotinib was tested in the phase 2 ALTER 1202 trial. Compared to placebo in 120 patients with SCLC who had received at least two prior lines of therapy, anlotinib improved the median PFS ( $4.1 \mathrm{~m}$ versus $0.7 \mathrm{~m})$ and the median OS $(7.3 \mathrm{~m}$ versus $4.9 \mathrm{~m})$ with improvement in disease control rate $(71.6 \%$ versus 13.2\%). Adverse effects were similar to other TKIs, and included hypertension, anorexia, fatigue, and hand-foot-syndrome [40].

The ALTER0302 phase 2 clinical trial investigated anlotinib in comparison with placebo in 117 patients in the third line treatment for ES-SCLC. Results were also promising, with anlotinib therapy resulting in significantly improved PFS (4.8 m versus $1.2 \mathrm{~m}$ ) and objective response rate (ORR) (10\% versus $0 \%$ ). There was a non-significant trend towards improvement in median OS (9.3 $\mathrm{m}$ versus $6.3 \mathrm{~m})[38]$.

\section{DNA Damage Response Targeting}

DNA damage response (DDR) pathways are intricate and overlapping systems to maintain genomic integrity in the face of DNA damage and stressors [41]. In SCLC, loss of TP53 and RB, together with 
the activation of oncogenic MYC and SOX2, results in rapid carcinogenesis where cancer cells become dependent on intact DDR pathways for survival [42,43]. Proteomic and transcriptomic analyses have identified a number of dysregulated DDR pathways such as Poly (ADP-ribose) polymerase (PARP1), checkpoint kinase 1 (CHK1), ataxia telangiectasia mutated (ATM), ataxia telangiectasia and Rad3-related protein (ATR), and WEE1 G2 checkpoint kinase [44-48]. Preclinical evidence also indicates that the compounds targeting these genes might be promising therapeutic options in SCLC. Moreover, targeting DDR machinery is also believed to reverse platinum resistance in this disease [49].

\subsection{PARP Inhibitors}

PARP is a family of nuclear enzymes involved in DDR where it plays a key role in the repair of single strand breaks (SSBs) [42]. Inhibition of PARP results in the conversion of SSBs to double strand breaks (DSBs) and subsequent apoptosis [42]. PARP-1 inhibitors have been successfully utilised in BRCA mutated cancers with homologous repair deficiency (HRD), e.g., ovarian cancer, and in the context of synthetic lethality [50]. In SCLC however, BRCA mutations are not common and PARP inhibition is dependent on a high level of intrinsic stress and genomic instability [44]. Therefore, preclinical studies have shown only limited single-agent cytotoxicity with PARP inhibitors [51] and alternative strategies of combining PARP inhibitors with DNA damaging cytotoxics provided preclinical evidence of potentiation of therapeutic efficacy [44,51-53]. Several PARP inhibitors such as, talazoparib, veliparib, niraparib, and olaparib, are being evaluated in combination with chemotherapy and other novel agents for patients with newly diagnosed or relapsed SCLC.

A phase 1 dose escalation study of veliparib in combination with carboplatin and etoposide was conducted in multiple solid tumours, which included 25 patients with ES-SCLC. The combination showed an impressive response rate of $84 \%$ but an increase in haematological toxicities, favouring a synergistic effect [54]. A subsequent phase 2 study of this combination in ES-SCLC in the first line setting is ongoing (NCT2289690). In another first line phase II study (ECOG-ACRIN 2511), efficacy of velaprib plus chemotherapy has been disappointing with a modest improvement in PFS (6.1 m versus $5.5 \mathrm{~m}, \mathrm{HR} 0.75, p=0.06$ ) but not OS [55].

Talazoparib has been evaluated in a number of BRCA mutant solid malignancies. In SCLC, 23 patients with platinum sensitive disease received single agent talazoparib, and at the established MTD of $1 \mathrm{mg}$, six patients had a partial response (PR) or stable disease (SD), while the median PFS was 11.1 weeks [56].

PARP inhibitors are also being investigated in the maintenance setting in patients with SCLC, who have not progressed after first line chemotherapy or chemoradiation. The phase 2 STOMP trial, showed no significant benefit of olaparib as a maintenance treatment compared to placebo [57]. In an ongoing phase 3 trial, niraparib is being compared to placebo as maintenance therapy in Chinese patients with ES-SCLC [58].

In relapsed ES-SCLC, a phase 2 study investigated temozolomide plus veliparib or placebo. There was a significant improvement in ORR $(39 \%$ versus $14 \%, p=0.016)$ but not in PFS or OS [59]. A subgroup of patients with high schlafen family member 11 (SLFN11) protein expression, had improved survival with the addition of veliparib [59]. Olaparib combined with temozolomide after at least one prior line of therapy showed an early indication of efficacy with 12 out of 29 patients showing a response and a reported median PFS and OS of 87 and 220 days, respectively [60]. Myelosuppression was the most common adverse event.

PARP inhibitors in combination with other non-cytotoxic therapies are being investigated. In preclinical models, Olaparib in combination with cediranib (VEGF inhibitor) showed evidence for efficacy [61]. In another phase 2 trial, patients with relapsed SCLC received durvalumab in combination with olaparib, but the trial did not meet its pre-set efficacy endpoint of ORR [62]. Ongoing trials of PARP inhibitors in various combinations in SCLC are shown in Table 1. 
Table 1. Ongoing clinical trials of Poly (ADP-ribose) polymerase (PARP)inhibitors in small cell lung cancer (SCLC).

\begin{tabular}{|c|c|c|c|c|}
\hline Indication & Phase & Treatment/Intervention & Primary Outcome & $\begin{array}{l}\text { ClinicalTrials.gov } \\
\text { Identifier }\end{array}$ \\
\hline $\begin{array}{l}\text { ES-SCLC } \\
\text { following response to first line } \\
\text { platinum-based chemotherapy }\end{array}$ & III & $\begin{array}{l}\text { Niraparib } \\
\text { Vs. } \\
\text { Placebo }\end{array}$ & $\begin{array}{l}\text { PFS } \\
\text { OS }\end{array}$ & NCT03516084 \\
\hline $\begin{array}{l}\text { ES-SCLC } \\
\text { following response to first line } \\
\text { platinum-based chemotherapy }\end{array}$ & $\mathrm{Ib} / \mathrm{II}$ & $\begin{array}{c}\text { Niraparib plus } \\
\text { temozolomide } \\
\text { Vs. } \\
\text { Best supportive care }\end{array}$ & $\begin{array}{l}\text { RP2D } \\
\text { PFS }\end{array}$ & NCT03830918 \\
\hline $\begin{array}{l}\text { Multiple tumours including } \\
\text { Relapsed/refractory SCLC }\end{array}$ & $\mathrm{I} / \mathrm{II}$ & CRLX101 plus olaparib & $\begin{array}{c}\text { RP2D/MTD } \\
\text { PFS (Expansion) }\end{array}$ & NCT02769962 \\
\hline $\begin{array}{c}\text { ES-SCLC, following response } \\
\text { to first line platinum-based } \\
\text { chemotherapy }\end{array}$ & II & Rucaparib plus nivolumab & PFS & NCT03958045 \\
\hline $\begin{array}{l}\text { Multiple tumours including } \\
\text { relapsed SCLC }\end{array}$ & $\mathrm{I} / \mathrm{II}$ & $\begin{array}{c}\text { Olaparib plus MEDI4736 } \\
\text { Vs. } \\
\text { Olaparib plus MEDI4736 } \\
\text { plus bevacizumab }\end{array}$ & $\begin{array}{l}\text { DCR } \\
\text { Safety and } \\
\text { tolerability } \\
\text { ORR }\end{array}$ & NCT02734004 \\
\hline $\begin{array}{l}\text { Multiple advanced tumours } \\
\text { including LS- or ES-SCLC } \\
\text { At least one prior line } \\
\text { platinum-based chemotherapy }\end{array}$ & II & Cediranib plus olaparib & ORR & NCT02498613 \\
\hline
\end{tabular}

\subsection{CHK and WEE Inhibition}

CHK1 along with other proteins such as WEE1 and ATR participates in the regulation of homologous repair and plays a key role in the DNA damage-dependent cell cycle arrest in cells with TP53 loss [63]. Inhibition of CHK1 appears to have a therapeutic effect in tumours prone to replication stress [63]. In a preclinical study of prexasertib (CHK1 inhibitor), Sen et al. demonstrated its efficacy as monotherapy and improved responses when combined with cisplatin or olaparib. Their efficacy was particularly enhanced in the context of MYC amplification or protein overexpression [45]. Prexasertib is being investigated in an ongoing phase 2 trial in patients with ES-SCLC [64].

The DDR protein WEE1 is involved in the inhibition cyclin dependent kinases via phosphorylation and subsequently halts the cell cycle, allowing for DNA repair [65]. Pre-clinical studies have shown efficacy of WEE1 inhibition [66,67]. Of particular interest is a compound AZD1775, which in preclinical SCLC models has demonstrated synergy with olaparib. The combination was found to be more active than cisplatin and etoposide chemotherapy [68]. AZD1775 has been investigated in a phase 1 study in combination with chemotherapy (cisplatin, carboplatin, or gemcitabine) in patients with refractory solid tumours and found to be safe and tolerable [69]. Of 176 evaluable patients, $10 \%$ had a PR and $53 \% \mathrm{SD}$, and the RR was favourable in patients with TP53 mutation compared with the wild type (21\% versus 12\%) [69]. AZD1775 is currently being evaluated in two ongoing phase 2 trials in relapsed SCLC (NCT02593019, NCT02688907).

\section{Epigenetic Targeting}

\subsection{Aurora Kinase Inhibition}

Aurora kinases A and B (AURK A/B) are serine/threonine kinases that play key roles in the regulation of mitosis. In the absence of $\mathrm{p} 53$, AURK $\mathrm{A} / \mathrm{B}$ provide growth advantage, particularly in MYC altered SCLC [70]. Preclinical studies have demonstrated activity of AURK A/B inhibitors in SCLC [71,72]. 
Alisertib, an inhibitor of AURK A, was investigated in a phase 1/2 trial of multiple tumour types including SCLC [73]. In the phase 2 part, alisertib as a monotherapy showed a PR in 10 of 48 patients with SCLC [74]. In another study, alisertib in combination with paclitaxel in relapsed SCLC, showed improvement in PFS (101 days) compared to 66 days with placebo and also a trend towards improvement in OS [75]. This agent is being investigated further in SCLC. LY3295668 Erbumine is another AURK A inhibitor being tested in ES-SCLC (NCT03898791). Chiauranib, a multiple kinase inhibitor including AURK B, is currently being investigated in a phase 1 trial in patients with SCLC (NCT03216343).

\subsection{Lurbinectedin}

Lurbinectedin is a novel and selective inhibitor of oncogenic transcription. By inhibiting trans-activated RNA polymerase II transcription, it causes double stranded DNA breaks leading to apoptosis [76]. Further, by inhibiting transcription in the tumour associated macrophages, lurbinectedin downregulates immune-suppressive cytokines such as interleukin-6 (IL-6), interleukin-8 (IL-8), C-C motif chemokine 2 (CCL2) and VEGF [77]. A phase 1 study of lurbinectedin in combination with doxorubicin showed promising activity with a complete response (CR) rate of $8 \%$ and PR rate of 50\% [76]. Outcomes were more favourable in patients with platinum-sensitive disease than refractory, with a reported median PFS of 5.8 months compared with 3.5 months, respectively. The main grade three or more adverse effects included myelosuppression $(22.9 \%)$ and fatigue (6.7\%) [76].

Efficacy as monotherapy has been demonstrated in two phase 2 studies. A study by Paz-Ares et al. included 105 patients with ES-SCLC, in which the ORR was 35.2\%. Outcomes were more favourable in patients with sensitive disease, with median OS of 11.9 months compared to only 5.0 months in patients with refractory disease [78]. Another basket study by Perez et al. showed an ORR of 39.3\% with overall clinical benefit rate of 50.8\% in 61 evaluable patients with recurrent ES-SCLC. The reported median PFS was 4.2 months. [79]

With promising early phase results, lurbinectedin has received orphan drug designation by the United States Food and Drug Administration (FDA) in 2019. An ongoing randomised phase III ATLANTIS trial of lurbinectedin plus doxorubicin compared to investigator's choice chemotherapy CAV (cyclophosphamide, doxorubicin, vincristine) or topotecan has completed accrual and should provide additional evidence of the efficacy in SCLC [80].

\subsection{Carfilzomib}

Carfilzomib is a selective proteasome inhibitor being investigated in a number of malignancies including SCLC. The safety of carfilzomib in combination with irinotecan was established in a phase 1 trial [81]. This combination was further evaluated in a phase 2 trial of 62 relapsed SCLC patients. The median PFS of 3.6 months and median OS of 6.9 months was observed and the results were similar for patients with both platinum sensitive and refractory disease [82].

In another Phase $1 \mathrm{~b}$ study in previously untreated ES-SCLC, carfilzomib was administered with carboplatin and etoposide and continued as monotherapy in patients with at least stable disease. The combination was quite toxic with $75 \%$ of patients having grade three or four adverse effects. Preliminary efficacy results included ORR of 16/30 (53.3\%) and median PFS of 4.4 months (95\% CI 3.2-5.8) [83].

Other dysregulated epigenetic processes, such as gene promoter methylation and histone acetylation, have also been targeted in SCLC. Vorinostat and belinostat, the two histone deacetylase (HDAC) inhibitors, have synergistic activity when added to chemotherapy $[84,85]$. Clinical trials investigating the combination of vorinostat (NCT00702962) and belinostat (NCT00926640) with platinum and etoposide in the first line treatment of patients with ES-SCLC are in progress. 


\section{Cell Cycle Targeting}

\section{CDK4/6 Inhibitors}

Cyclin dependent kinases (CDK) 4/6 promote the proliferation of different cell types including haematopoietic stem progenitor cells (HSPCs) by phosphorylating retinoblastoma protein $(\mathrm{Rb})$ [86].

CDK4/6 inhibitors are being investigated and used in a number of malignancies, and have proven efficacy in breast cancer [87]. In RB deficient SCLC mouse models, CDK4/6 inhibitors have shown a myeloprotective and synergistic anti-cancer effect when combined with cisplatin. In preclinical mouse models, G1T28 induced CDK4/6 inhibition not only led to the protection of immune cells from cytotoxic effects of cisplatin but also resulted in tumour volume reduction [86]. Further trials of G1T28 in combination with chemotherapy in first (NCT02499770) and second line are ongoing (NCT02514447).

Trilaciclib, another CDK4/6 inhibitor was investigated in a phase 2 trial of 91 previously treated ES-SCLC. Treatment with trilaciclib and topotecan resulted in a significant reduction in occurrence and duration of severe neutropenia, compared with placebo ( $40.6 \%$ versus $75.6 \%$ and two days versus eight days, respectively), as well as a reduced need for blood transfusions, growth factor support, and dose reductions [88]. Larger studies are needed to determine if CDK4/6 inhibitors will have a clinically meaningful place in the management of SCLC. However, CDK4/6 inhibitors act primarily by blocking RB phosphorylation and hence inducing G1 cell cycle arrest [89]. The tumour cells with RB loss by definition may be resistant to these agents, presumably due to lack the canonical target of these agents. Therefore, the rare RB1 WT SCLC ( 10\%) should be more sensitive to CDK4/6 inhibitors. A clinical trial in this setting has already been planned (NCT 04010357).

\section{Targeting Immune Mechanisms}

Since SCLC exhibit characteristic features of response to immunotherapies (high somatic mutational burden, genomic instability, and association with paraneoplastic syndromes) [7,90], a stronger rationale to target this mechanism had emerged. Thus, several trials including immune checkpoints inhibitors (CPIs), tumour vaccine, antigenic targets, and adoptive cellular immunotherapy in SCLC were initiated. However, the results in SCLC have been somewhat disappointing so far and certainly inferior to what has been achieved in other cancer types such as renal cell carcinoma, melanoma, and non-small cell lung cancer. To date, the largest data available is with CPIs that target cytotoxic T-lymphocyte-associated protein 4 (CTLA-4) and programmed death protein 1 (PD-1), summarised as follows.

A phase 3 trial by Reck et al. investigated chemotherapy (platinum agent plus etoposide) plus ipilimumab, a CTLA-4 antibody, versus chemotherapy plus placebo in the first line setting of ES-SCLC. The dosing of ipilimumab was $10 \mathrm{mg} / \mathrm{kg}$ every three weeks for four doses followed by a maintenance dose of ipilimumab every 12 weeks. Results were disappointing with no clinically significant difference in PFS or OS [91]. Similarly, treatment with single agent anti-PD-1 antibody, nivolumab, did not improve response rates or survival over standard chemotherapy in patients with relapsed SCLC [92]. Subsequent to the observation of relative lack of efficacy, it was postulated that low expression of programmed death-ligand 1 (PD-L1) and an overall immunosuppressive environment characterised by the downregulation of major histocompatibility complex (MHC) class 1, poor T cell infiltration, and presence of myeloid-derived suppressor cells in SCLC, single agent check-point blockade may not be efficacious on its own and combination strategies thereafter have emerged.

The phase 1/2 CHECKMATE-032 trial included a patient cohort with ES-SCLC having progressed after at least one prior line of therapy. This trial investigated nivolumab monotherapy compared to nivolumab plus ipilimumab at two different doses, with ORR as the primary endpoint [93]. In an updated analysis of this cohort, the ORR was $11 \%$ in the nivolumab monotherapy arm, and $23 \%$ in the nivolumab $1 \mathrm{mg} / \mathrm{kg}$ and ipilimumab $3 \mathrm{mg} / \mathrm{kg}$ arm. Median PFS was 1.4 months in the nivolumab monotherapy and nivolumab $3 \mathrm{mg} / \mathrm{kg}$ and ipilimumab $1 \mathrm{mg} / \mathrm{kg}$ arms, and 2.6 months in the nivolumab $1 \mathrm{mg} / \mathrm{kg}$ and ipilimumab $3 \mathrm{mg} / \mathrm{kg}$ arms, while the median OS was 4.4 and 7.7 months, respectively [94]. Responses occurred regardless of the PDL1 expression. In an exploratory analysis, the ORR was 
significantly higher with nivolumab plus ipilimumab in patients with a high tumour mutational burden (TMB) (46\%) compared with medium (16\%) and low TMB (22\%), respectively. Based on these results, nivolumab was FDA approved for SCLC as a third line treatment in August 2018.

Nivolumab and ipilimumab $(1 \mathrm{mg} / \mathrm{kg}$ and $3 \mathrm{mg} / \mathrm{kg}$, respectively) followed by maintenance nivolumab ( $240 \mathrm{mg}$ flat dose) is being investigated in the phase 2 , second line BIOLUMA trial. Interim data from the all-comer cohort $(\mathrm{N}=18)$ has shown an ORR of $38.8 \%$ and a disease control rate of 55.5\% [95]. The combination was quite toxic with two patients dying of immune related adverse effects (pneumonitis and encephalitis). This study later amended the protocol to include only patients with high TMB to ensure balance of treatment benefits and risks.

Based on encouraging results from the Checkmate- 032 trial, the CheckMate- 451 phase 3 trial in 834 patients with ES-SCLC investigating maintenance nivolumab or nivolumab with ipilimumab following the first line platinum doublet was initiated. Unfortunately, this trial did not meet its primary endpoint of OS [96].

Another anti-PD1 agent pembrolizumab has been investigated in the phase $1 \mathrm{~b}$ Keynote 028 and phase 2 Keynote 158. Both studies included patients with previously treated advanced SCLC. In Keynote 028 patients were required to be programmed death-ligand 1 (PDL1) positive (defined as $\geq 1 \%$ ), but this was not required in Keynote 158 . The primary outcome ORR was $33.3 \%$ and $18.7 \%$, respectively $[97,98]$. In a pooled analysis of these two trials, involving 83 patients ORR was $19.3 \%(95 \%$ CI, 11.4-29.4), with 2 CRs and 14 PRs. Median PFS was two months (95\% CI, 1.9-3.4) and median OS 7.7 months (95\% CI, 5.2-10.1). In June 2019, the FDA approved pembrolizumab for metastatic SCLC in patients who failed at least two prior lines of treatment.

Due to the aggressive nature of this disease, only a minority of patients will be expected to survive and hence benefit from third line immunotherapy treatment. A number of early phase trials have therefore been performed. The most promising results thus far have been with atezolizumab (anti PD-L1 antibody). The phase 3 IMpower133 trial evaluated chemotherapy (platinum agent plus etoposide) with atezolizumab or placebo in patients with ES-SCLC in the first line setting. The atezolizumab/placebo were continued as maintenance therapy in responders or those with SD. There was a significant improvement in the median OS in the atezolizumab group (12.3 m versus $10.3 \mathrm{~m})$ and the median PFS (5.2 $\mathrm{m}$ versus $4.3 \mathrm{~m}$ ) [99]. Based on these results the FDA has recently approved atezolizumab as a first line treatment for ES-SCLC in combination with chemotherapy. Almost similar results were produced by the phase III CASPIAN trial when durvalumab was added to the chemotherapy in first line treatment of ES-SCLC [100] (Table 2). 
Table 2. Clinical trials involving immune checkpoint inhibitors in SCLC.

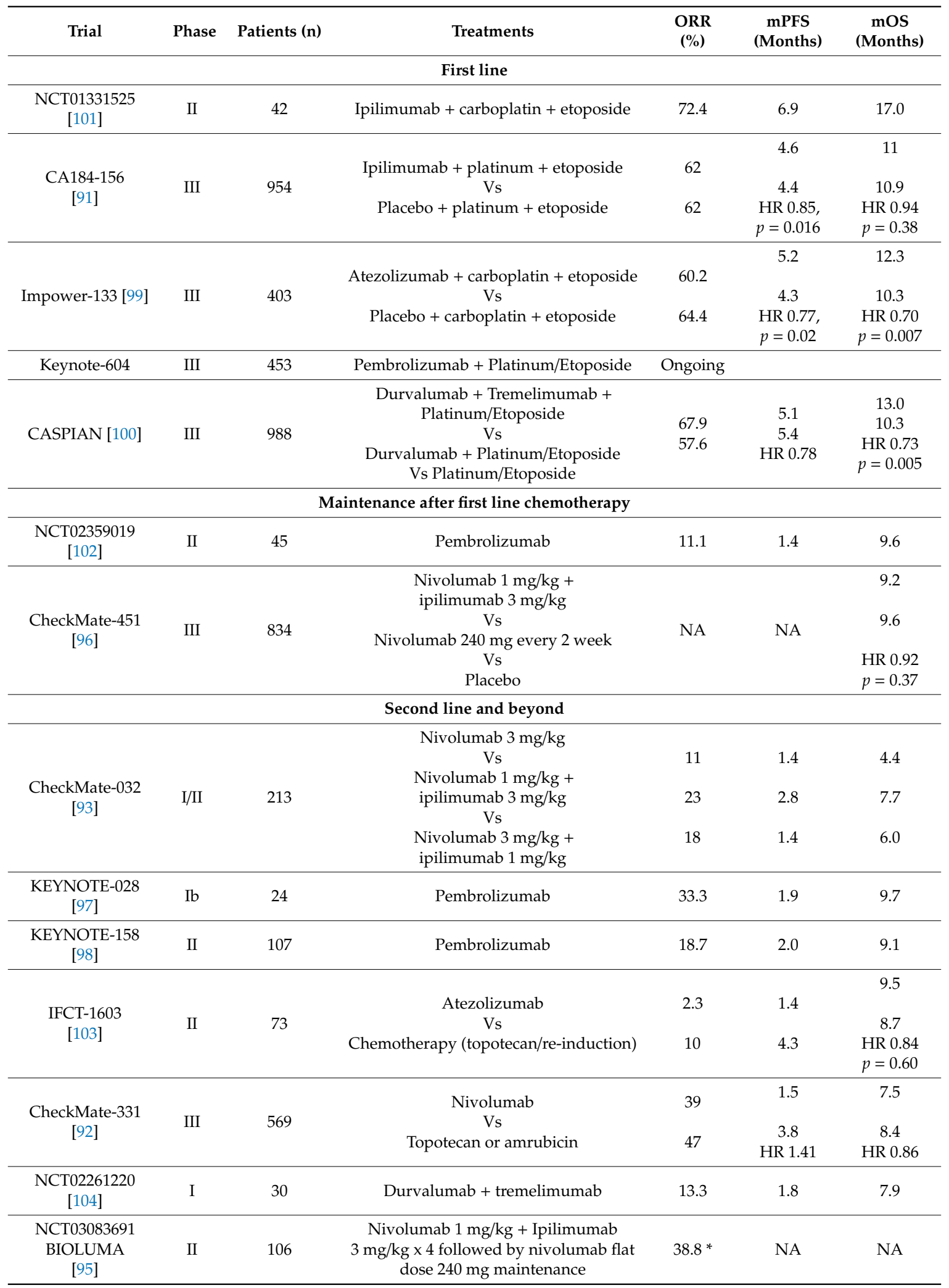

${ }^{*}$ All-comer cohort $\mathrm{N}=18$, trial is ongoing with data on high tumour mutational burden (TMB) patients pending. HR: hazard ratio; mOS: median overall survival; mPFS: median progression free survival; NA: not available; ORR: objective response rate; SCLC: small cell lung cancer. 
Table 2 summarises the completed and ongoing clinical trials of immune check point inhibitors in SCLC.

Several tumour vaccines demonstrated limited efficacy when investigated in SCLC. Direct antigen targeting of ganglioside antigen (GD3) with BEC2/bacilli Calmette-Guerin (BCG) showed promising preclinical and early clinical activity [105] but failed in a phase II trial [106]. More recently tumour antigen ganglioside fucosyl-GM1 (FucGM1) targeting with BMS-986012, a novel, nonfucosylated, IgG antibody, showed promising preclinical activity [107]. Further phase I studies in treatment naïve as well as in relapsed/refractory SCLC are ongoing (NCT02815592, NCT02247349). There has not been much success with anti-cancer vaccines. As an example, INGN-225, a dendritic cell based p53 vaccine, did not improve survival, despite improving immune response with enhanced chemotherapy effect in preclinical models $[108,109]$. Interferons (IFN) were amongst the first immunotherapy cytokines evaluated in SCLC showing survival benefit in a phase II trial [110] but also failed in phase III [111].

\section{Advances in Biomarkers}

To date there has been limited incorporation of informative biomarkers in SCLC clinical trials due in part to lack of quality tumour samples and the absence of clinically relevant biomarkers for predicting efficacy of cytotoxic chemotherapy. More concerningly, most of the available tumour samples were obtained at a single timepoint in a treatment naïve baseline scenario, that gave limited insight into the complexities of tumour heterogeneity, evolution, and drug resistance mechanisms. Such biomarker studies require tumour samples from the chemoresistant or chemorefractory patients, which are not always available, thus leading to a heavy reliance on conventional cell lines that may not accurately reflect the complex biological and genomic heterogeneity of the human disease [112]. As a result, efforts to explore readily accessible surrogates for tumour tissue in SCLC have expanded. Multiple studies have demonstrated the utility of circulating bio-markers, that may serve as important and renewable recourses to study resistant mechanisms and develop precision medicine [113].

\subsection{Progress in Liquid Biopsies}

Plasma circulating tumour cells (CTCs) and circulating cell free DNA (cfDNA) are emerging as potentially useful rapid tools in SCLC and other malignancies. Such 'liquid biopsies' have potential utility in serving as a rapid non-invasive diagnostic tool including identification of mutations, and as predictive and prognostic biomarkers. With potential scope for mutational analysis and serial testing over time to monitor patients' responses to therapies and disease recurrence or progression, liquid biopsies have been deemed an attractive recent technological development.

In SCLC, CTCs have been implicated in metastatic process and found to correlate with disease extent [114]. Studies have demonstrated that baseline CTC count is prognostic, and reduction in the CTC count following initial cycles of chemotherapy correlate with patient outcomes [114-117]. In a correlative study performed by Bellani et al. (investigating chemotherapy, vismodegib, and cixutumumab in newly diagnosed ES-SCLC), significant results in efficacy were only found in an exploratory analysis looking at patients with low CTC counts at baseline compared to those with high baseline CTC counts [35]. Further, Messaritakis et al. derived blood samples from 66 patients with SCLC, and found CTC level to reduce significantly from baseline after the commencement of treatment, followed by a significant increase at relapse [118]. Other studies however have failed to show such a correlation [119]. While several technologies have been utilised to explore the clinical utility of CTCs, technical differences such as throughput, specificity, false-negative/false positive rates, and cost issues need to be overcome for uniformity in results and thus widespread application.

With advances in next-generation sequencing (NGS) and single-cell sequencing (SCS) technologies, scientists can obtain the complete genome of a CTC and compare it with corresponding primary and metastatic tumours [113,120]. Molecular analysis of CTCs has predicted chemosensitive or refractory disease and subsequent patient outcomes [121]. With specific focus on copy number aberrations (CNAs), Su et al. showed utility of single cell sequencing of CTC with regards to survival, 
chemotherapy response, and heterogeneity by tracing allele specific CNAs in CTCs isolated at different timepoints of chemotherapy [120]. Phenotypic heterogeneity was also found with regards to expression of Bcl-2, CK, Vim, and M30 [120]. Implantation of CTCs into immunodeficient mice to generate CTC-derived explants may become a useful alternative to patient derived xenograft (PDX) models to effectively mirror the donor tumour. Further developments in this area are ongoing.

A number of studies have shown a promising viability of cell free DNA (cfDNA), as an alternative to tissue genotyping [122-124]. In a study of 27 patients with SCLC, Almodovar et al. used cfDNA assay to detect somatic variants (including TP53, RB1, NOTCH, KIT, PTEN, and MYC). They were also able to track tumour recurrence before radiographic evidence of progression by longitudinal tracking of mutational burden in cfDNA [125]. In the IMpower 133 trial, blood-based analysis of tumour mutational burden yielded high quality data for analysis, but no difference between atezolizumab and placebo was found. Few other clinical studies have confirmed the potential utility of cfDNA. Further, bio-marker data from the Keynote-604 and the CASPIAN trials are awaited.

\subsection{Potential Biomarkers}

SFLN11, implicated in DNA damage repair deficiency is an emerging marker of great interest. Using patient derived xenograft models, Gardner et al. demonstrated that suppression of SFLN11 is associated with acquired chemoresistance in SCLC [126]. However, SLFN11 as a predictive biomarker for response to PARP inhibitors has been more promising. In a preclinical study, integrated proteomic, transcriptomic, and genomic analyses showed that high SLFN11 predicted response to PARP inhibition, whereas DDR and HRD did not [52]. In the phase 2 trial of veliparib with temozolomide, SLFN11 positive tumours had improved survival, while PARP-1 expression did not predict clinical outcome [59]. In another study, high levels of DNA repair proteins were predictive, and that activation of the PI3K pathway was associated with greater resistance to PARP inhibition [53].

Tumour mutational burden (TMB) has emerged as a possible key predictor of the response to immunotherapeutic agents in SCLC. In the Checkmate-032 study, employing whole exome sequencing (WES), high TMB (defined as $\geq 248$ mutations) had superior outcomes in comparison to patients with lower TMB, reporting one year OS rates of $35 \%$ with nivolumab monotherapy and $62 \%$ for ipilimumab and nivolumab therapy [127]. In a retrospective analysis by et al., targeted NGS evaluated TMB in SCLC as a predictive biomarker of response to immunotherapy. They also found high TMB correlated with superior outcomes with immunotherapy, but not with chemotherapy [128]. Conversely, IMpower133 investigating atezolizumab in SCLC did not find a clear association between blood based TMB and outcomes [99]. In a study by Gu et al. a positive correlation between TMB and KMT2C mutation may suggest a possible surrogate marker, but clinical confirmation is required [129]. Further data on clinical utility of TMB in SCLC is awaited.

The ongoing BIOLUMA trial evaluates efficacy and safety of nivolumab and ipilimumab in lung cancer with a broad translational program to identify potential biomarkers predictive of response and/or resistance including WES of serial biopsies, functional analysis of peripheral T-cells, and gut microbiome analyses [95].

Unlike NSCLC, PDL1 expression in SCLC is less common and not proven to be predictive. In a study by Carvajal-Hausdorf et al. involving 90 SCLC samples, only 7.3\% expressed PDL1; however, they found $\mathrm{B} 7-\mathrm{H} 3$ being expressed in almost $65 \%$ and may be associated with immune invasion in SCLC [130].

Multiple other biomarkers have been identified in SCLC and their potential in clinical practice remains an active area of research. Examples include $M Y C$ amplification and response to aurora kinase inhibitors [131], MicroRNAs and chemoresistance [132] and CD47 expression and immune escape [133]. Given phenotypic and genomic heterogeneity of the disease, a single biomarker may not be sufficient to predict the response to therapy. 


\section{Conclusions}

Novel enabling technologies and tools for basic and clinical research aligned with collaborative focus on experimental and analytical capabilities addressing heterogeneity and complexity of biology in SCLC, have greatly improved our understanding of the disease. Concerted efforts are underway to underpin the genomics, molecular profiling, resistance mechanisms, and novel therapies in SCLC. Considerable progress in understanding the molecular biology has been made recently. In particular, the converging genomic data from human and mouse tissue samples leading to an evolving classification of SCLC into molecular subtypes is being anticipated as a major development. Based on these emerging genomic data and a focus on several potential targets, clinical trials are carefully being planned. To date, therapeutic targeting of DNA damage repair and immune mechanisms have yielded encouraging signals. However, extreme plasticity of SCLC due to presence and evolution of various subpopulations and their functional interactions is posing a high degree of hindrance. More refined and diversified therapeutic strategies connected with basic research to bridge the gaps in the knowledge of the disease as well as identification of clinically meaningful biomarkers will be needed. To achieve these goals, accurate preclinical models and high-quality tissue samples are essential.

Author Contributions: Writing, review and editing, C.L., M.A.; supervision, M.A.

Funding: This research received no external funding.

Conflicts of Interest: The authors declare no conflict of interest.

\section{References}

1. Rossi, A.; Di Maio, M.; Chiodini, P.; Rudd, R.M.; Okamoto, H.; Skarlos, D.V.; Früh, M.; Qian, W.; Tamura, T.; Samantas, E.; et al. Carboplatin- or Cisplatin-Based Chemotherapy in First-Line Treatment of Small-Cell Lung Cancer: The COCIS Meta-Analysis of Individual Patient Data. J. Clin. Oncol. 2012, 30, 1692-1698. [CrossRef] [PubMed]

2. Noone, A.M.; Cronin, K.A.; Altekruse, S.F.; Howlader, N.; Lewis, D.R.; Petkov, V.I.; Penberthy, L. Cancer Incidence and Survival Trends by Subtype Using Data from the Surveillance Epidemiology and End Results Program, 1992-2013. Cancer Epidemiol. Biomark. Prev. 2017, 26, 632-641. [CrossRef] [PubMed]

3. Treat, J.; Huang, C.H.; Lane, S.R.; Levin, J. Topotecan in the treatment of relapsed small cell lung cancer patients with poor performance status. Oncologist 2004, 9, 173-181. [CrossRef] [PubMed]

4. Sgambato, A.; Casaluce, F.; Maione, P.; Rossi, A.; Sacco, P.C.; Panzone, F.; Ciardiello, F.; Gridelli, C. Medical treatment of small cell lung cancer: State of the art and new development. Expert Opin. Pharmacother. 2013, 14, 2019-2031. [CrossRef]

5. Bunn, P.A.; Minna, J.D.; Augustyn, A.; Gazdar, A.F.; Ouadah, Y.; Krasnow, M.A.; Berns, A.; Brambilla, E.; Rekhtman, N.; Massion, P.P.; et al. Small Cell Lung Cancer: Can Recent Advances in Biology and Molecular Biology Be Translated into Improved Outcomes? J. Thorac. Oncol. 2016, 11, 453-474. [CrossRef]

6. George, J.; Lim, J.S.; Jang, S.J.; Cun, Y.; Ozretić, L.; Kong, G.; Leenders, F.; Lü, X.; Fernandez-Cuesta, L.; Bosco, G.; et al. Comprehensive genomic profiles of small cell lung cancer. Nature 2015, 524, 47-53. [CrossRef]

7. Peifer, M.; Fernandez-Cuesta, L.; Sos, M.L.; George, J.; Seidel, D.; Kasper, L.H.; Plenker, D.; Leenders, F.; Sun, R.; Zander, T.; et al. Integrative genome analyses identify key somatic driver mutations of small cell lung cancer. Nat. Genet. 2012, 44, 1104-1110. [CrossRef]

8. Sonkin, D.; Vural, S.; Thomas, A.; Teicher, B.A. Neuroendocrine negative SCLC is mostly RB1 WT and may be sensitive to CDK4/6 inhibition. BioRxiv 2019, BioRxiv:516351. [CrossRef]

9. Sabari, J.K.; Lok, B.H.; Laird, J.H.; Poirier, J.T.; Rudin, C.M. Unravelling the biology of SCLC: Implications for therapy. Nat. Rev. Clin. Oncol. 2017, 14, 549-561. [CrossRef]

10. Ross, J.S.; Wang, K.; Elkadi, O.R.; Tarasen, A.; Foulke, L.; Sheehan, C.E.; Otto, G.A.; Palmer, G.; Yelensky, R.; Lipson, D.; et al. Next-generation sequencing reveals frequent consistent genomic alterations in small cell undifferentiated lung cancer. J. Clin. Pathol. 2014, 67, 772-776. [CrossRef]

11. Pillai, R.N.; Owonikoko, T.K. Small cell lung cancer: Therapies and targets. Semin. Oncol. 2014, 41, $133-142$. [CrossRef] [PubMed] 
12. Gazdar, A.F.; Carney, D.N.; Nau, M.M.; Minna, J.D. Characterization of variant subclasses of cell lines derived from small cell lung cancer having distinctive biochemical, morphological, and growth properties. Cancer Res. 1985, 45, 2924-2930. [PubMed]

13. Rudin, C.M.; Poirier, J.T.; Byers, L.A.; Dive, C.; Dowlati, A.; George, J.; Heymach, J.V.; Johnson, J.E.; Lehman, J.M.; MacPherson, D.; et al. Molecular subtypes of small cell lung cancer: A synthesis of human and mouse model data. Nat. Rev. Cancer 2019, 19, 289-297. [CrossRef] [PubMed]

14. McColl, K.; Wildey, G.; Sakre, N.; Lipka, M.B.; Behtaj, M.; Kresak, A.; Chen, Y.; Yang, M.; Velcheti, V.; Fu, P.; et al. Reciprocal expression of INSM1 and YAP1 defines subgroups in small cell lung cancer. Oncotarget 2017, 8, 73745-73756. [CrossRef] [PubMed]

15. Carter, L.; Rothwell, D.G.; Mesquita, B.; Smowton, C.; Leong, H.S.; Fernandez-Gutierrez, F.; Li, Y.; Burt, D.J.; Antonello, J.; Morrow, C.J.; et al. Molecular analysis of circulating tumor cells identifies distinct copy-number profiles in patients with chemosensitive and chemorefractory small-cell lung cancer. Nat. Med. 2017, 23, 114-119. [CrossRef]

16. Borg, R.V.D.; Leonetti, A.; Tiseo, M.; Giovannetti, E.; Peters, G.J. Novel targeted strategies to overcome resistance in small-cell lung cancer: Focus on PARP inhibitors and rovalpituzumab tesirine. Expert Rev. Anticancer. Ther. 2019, 19, 461-471. [CrossRef] [PubMed]

17. McGranahan, N.; Swanton, C. Biological and Therapeutic Impact of Intratumor Heterogeneity in Cancer Evolution. Cancer Cell 2015, 28, 141. [CrossRef]

18. Maley, C.C.; Aktipis, A.; Graham, T.A.; Sottoriva, A.; Boddy, A.M.; Janiszewska, M.; Silva, A.S.; Gerlinger, M.; Yuan, Y.; Pienta, K.J.; et al. Classifying the evolutionary and ecological features of neoplasms. Nat. Rev. Cancer 2017, 17, 605-619. [CrossRef]

19. Amirouchene-Angelozzi, N.; Swanton, C.; Bardelli, A. Tumor Evolution as a Therapeutic Target. Cancer Discov. 2017, 7, 805-817. [CrossRef]

20. Fargion, S.; Carney, D.; Mulshine, J.; Rosen, S.; Bunn, P.; Jewett, P.; Cuttitta, F.; Gazdar, A.; Minna, J. Heterogeneity of cell surface antigen expression of human small cell lung cancer detected by monoclonal antibodies. Cancer Res. 1986, 46, 2633-2638.

21. Nong, J.; Gong, Y.; Guan, Y.; Yi, X.; Yi, Y.; Chang, L.; Yang, L.; Lv, J.; Guo, Z.; Jia, H.; et al. Author Correction: Circulating tumor DNA analysis depicts subclonal architecture and genomic evolution of small cell lung cancer. Nat. Commun. 2019, 10, 552. [CrossRef] [PubMed]

22. Suda, K.; Kim, J.; Murakami, I.; Rozeboom, L.; Shimoji, M.; Shimizu, S.; Rivard, C.J.; Mitsudomi, T.; Tan, A.-C.; Hirsch, F.R. Innate Genetic Evolution of Lung Cancers and Spatial Heterogeneity: Analysis of Treatment-Naïve Lesions. J. Thorac. Oncol. 2018, 13, 1496-1507. [CrossRef] [PubMed]

23. Lim, J.S.; Ibaseta, A.; Fischer, M.M.; Cancilla, B.; O’Young, G.; Cristea, S.; Luca, V.C.; Yang, D.; Jahchan, N.S.; Hamard, C.; et al. Intratumoural heterogeneity generated by Notch signalling promotes small-cell lung cancer. Nature 2017, 545, 360-364. [CrossRef] [PubMed]

24. Koch, U.; Radtke, F. Notch and cancer: A double-edged sword. Cell. Mol. Life Sci. 2007, 64, $2746-2762$. [CrossRef]

25. Byers, L.A.; Chiappori, A.; Smit, M.-A.D. Phase 1 study of AMG 119, a chimeric antigen receptor (CAR) T cell therapy targeting DLL3, in patients with relapsed/refractory small cell lung cancer (SCLC). J. Clin. Oncol. 2019, 37, TPS8576.

26. Rudin, C.M.; Pietanza, M.C.; Bauer, T.M.; Ready, N.; Morgensztern, D.; Glisson, B.S.; Byers, L.A.; Johnson, M.L.; Burris, H.A., 3rd; Robert, F.; et al. Rovalpituzumab tesirine, a DLL3-targeted antibody-drug conjugate, in recurrent small-cell lung cancer: A first-in-human, first-in-class, open-label, phase 1 study. Lancet Oncol. 2017, 18, 42-51. [CrossRef]

27. Saunders, L.R.; Bankovich, A.J.; Anderson, W.C.; Aujay, M.A.; Bheddah, S.; Black, K.; Desai, R.; Escarpe, P.A.; Hampl, J.; Laysang, A.; et al. A DLL3-targeted antibody-drug conjugate eradicates high-grade pulmonary neuroendocrine tumor-initiating cells in vivo. Sci. Transl. Med. 2015, 7, 302. [CrossRef]

28. Carbone, D.P.; Morgensztern, D.; Le Moulec, S.; Santana-Davila, R.; Ready, N.; Hann, C.L.; Glisson, B.S.; Dowlati, A.; Rudin, C.M.; Lally, S.; et al. Efficacy and safety of rovalpituzumab tesirine in patients With DLL3-expressing, $\geq 3$ rd line small cell lung cancer: Results from the phase 2 TRINITY study. J. Clin. Oncol. 2018, 36, 8507. [CrossRef] 
29. Malhotra, J.; Nikolinakos, P.; Leal, T.; Lehman, L.; Morgensztern, D.; Patel, J.D.; Wrangle, J.M.; Curigliano, G.; Dansin, E.; Greillier, L.; et al. Ph1/2 study of Rova-T in combination with nivolumab (Nivo) \pm ipilimumab (Ipi) for patients (pts) with 2L+ extensive-stage (ED) SCLC. J. Clin. Oncol. 2019, 37, 8516.

30. Giffin, M.J.; Lobenhofer, E.K.; Cooke, K.; Raum, T.; Stevens, J.; Beltran, P.J.; Coxon, A.; Hughes, P.E. Abstract 3632: BiTE@ antibody constructs for the treatment of SCLC. Immunology 2017, 77, 3632.

31. Giffin, M.; Cooke, K.; Lobenhofer, E.; Friedrich, M.; Raum, T.; Coxon, A. P3.12-03 Targeting DLL3 with AMG 757, a BiTE@ Antibody Construct, and AMG 119, a CAR-T, for the Treatment of SCLC. J. Thorac. Oncol. 2018, 13, S971. [CrossRef]

32. Justilien, V.; Fields, A.P. Molecular pathways: Novel approaches for improved therapeutic targeting of Hedgehog signaling in cancer stem cells. Clin. Cancer Res. 2015, 21, 505-513. [CrossRef] [PubMed]

33. Pietanza, M.C.; Litvak, A.M.; Varghese, A.M.; Krug, L.M.; Fleisher, M.; Teitcher, J.B.; Holodny, A.I.; Sima, C.S.; Woo, K.M.; Ng, K.K.; et al. A phase I trial of the Hedgehog inhibitor, sonidegib (LDE225), in combination with etoposide and cisplatin for the initial treatment of extensive stage small cell lung cancer. Lung Cancer 2016, 99, 23-30. [CrossRef] [PubMed]

34. Vestergaard, J.; Pedersen, M.W.; Pedersen, N.; Ensinger, C.; Tümer, Z.; Tommerup, N.; Poulsen, H.S.; Larsen, L.A. Hedgehog signaling in small-cell lung cancer: Frequent in vivo but a rare event in vitro. Lung Cancer 2006, 52, 281-290. [CrossRef]

35. Belani, C.P.; Dahlberg, S.E.; Rudin, C.M.; Fleisher, M.; Chen, H.X.; Takebe, N.; Velasco, M.R.; Tester, W.J.; Sturtz, K.; Hann, C.L.; et al. Vismodegib or cixutumumab in combination with standard chemotherapy for patients with extensive-stage small cell lung cancer: A trial of the ECOG-ACRIN Cancer Research Group (E1508). Cancer 2016, 122, 2371-2378. [CrossRef]

36. Watkins, D.N.; Berman, D.M.; Burkholder, S.G.; Wang, B.; Beachy, P.A.; Baylin, S.B. Hedgehog signalling within airway epithelial progenitors and in small-cell lung cancer. Nature 2003, 422, 313-317. [CrossRef]

37. Schaefer, E.; Braiteh, F.; Forster, M.; Talbot, D.; Chandler, J.; Richards, D.; Andre, V.; Estrem, S.; Pitou, C.; Tiu, R.; et al. Phase 1b/2 trial of taladegib (LY2940680), a Hh/Smo inhibitor, in combination with carboplatin and etoposide followed by taladegib maintenance in extensive-stage small-cell lung cancer. Eur. J. Cancer 2016, 69, S131-S132. [CrossRef]

38. Han, B.; Li, K.; Zhao, Y.; Li, B.; Cheng, Y.; Zhou, J.; Lu, Y.; Shi, Y.; Wang, Z.; Jiang, L.; et al. Anlotinib as a third-line therapy in patients with refractory advanced non-small-cell lung cancer: A multicentre, randomised phase II trial (ALTER0302). Br. J. Cancer 2018, 118, 654-661. [CrossRef]

39. Sun, Y.; Niu, W.; Du, F.; Du, C.; Li, S.; Wang, J.; Li, L.; Wang, F.; Hao, Y.; Li, C.; et al. Safety, pharmacokinetics, and antitumor properties of anlotinib, an oral multi-target tyrosine kinase inhibitor, in patients with advanced refractory solid tumors. J. Hematol. Oncol. 2016, 9, 105. [CrossRef]

40. Cheng, Y.; Wang, Q.; Li, K.; Shi, J.; Wu, L.; Han, B.; Chen, G.; He, J.; Wang, J.; Qin, H.; et al. OA13.03 Anlotinib as Third-Line or Further-Line Treatment in Relapsed SCLC: A Multicentre, Randomized, Double-Blind Phase 2 Trial. J. Thorac. Oncol. 2018, 13, S351-S352. [CrossRef]

41. Bartek, J.; Lukas, J. DNA damage checkpoints: From initiation to recovery or adaptation. Curr. Opin. Cell Boil. 2007, 19, 238-245. [CrossRef] [PubMed]

42. Foy, V.; Schenk, M.W.; Baker, K.; Gomes, F.; Lallo, A.; Frese, K.K.; Forster, M.; Dive, C.; Blackhall, F. Targeting DNA damage in SCLC. Lung Cancer 2017, 114, 12-22. [CrossRef] [PubMed]

43. Thomas, A.; Pommier, Y. Small cell lung cancer: Time to revisit DNA-damaging chemotherapy. Sci. Transl. Med. 2016, 8, 346. [CrossRef] [PubMed]

44. Byers, L.A.; Wang, J.; Nilsson, M.B.; Fujimoto, J.; Saintigny, P.; Yordy, J.; Giri, U.; Peyton, M.; Fan, Y.H.; Diao, L.; et al. Proteomic profiling identifies dysregulated pathways in small cell lung cancer and novel therapeutic targets including PARP1. Cancer Discov. 2012, 2, 798-811. [CrossRef]

45. Sen, T.; Tong, P.; Stewart, C.A.; Cristea, S.; Valliani, A.; Shames, D.S.; Redwood, A.B.; Fan, Y.H.; Li, L.; Glisson, B.S.; et al. CHK1 Inhibition in Small-Cell Lung Cancer Produces Single-Agent Activity in Biomarker-Defined Disease Subsets and Combination Activity with Cisplatin or Olaparib. Cancer Res. 2017, 77, 3870-3884. [CrossRef]

46. Sen, T.; Tong, P.; Diao, L.; Li, L.; Fan, Y.; Hoff, J.; Heymach, J.V.; Wang, J.; Byers, L.A. Targeting AXL and mTOR Pathway Overcomes Primary and Acquired Resistance to WEE1 Inhibition in Small-Cell Lung Cancer. Clin. Cancer Res. 2017, 23, 6239-6253. [CrossRef] 
47. Sen, T.; Tong, P.; Wang, J.; Byers, L.A. Abstract LB-132: Proteomic profiling identifies ATM expression level as a predictive biomarker to ATR and PARP inhibition in small cell lung cancer (SCLC). Clin. Trials 2016, 76, LB132.

48. Doerr, F.; George, J.; Schmitt, A.; Beleggia, F.; Rehkämper, T.; Hermann, S.; Walter, V.; Weber, J.-P.; Thomas, R.K.; Wittersheim, M.; et al. Targeting a non-oncogene addiction to the ATR/CHK1 axis for the treatment of small cell lung cancer. Sci. Rep. 2017, 7, 15511. [CrossRef]

49. Kelland, L. The resurgence of platinum-based cancer chemotherapy. Nat. Rev. Cancer 2007, 7, 573-584. [CrossRef]

50. Friedlander, M.; Banerjee, S.; Mileshkin, L.; Scott, C.; Shannon, C.; Goh, J. Practical guidance on the use of olaparib capsules as maintenance therapy for women with BRCA mutations and platinum-sensitive recurrent ovarian cancer. Asia Pac. J. Clin. Oncol. 2016, 12, 323-331. [CrossRef]

51. Owonikoko, T.K.; Zhang, G.; Deng, X.; Rossi, M.R.; Switchenko, J.M.; Doho, G.H.; Chen, Z.; Kim, S.; Strychor, S.; Christner, S.M.; et al. Poly (ADP) ribose polymerase enzyme inhibitor, veliparib, potentiates chemotherapy and radiation in vitro and in vivo in small cell lung cancer. Cancer Med. 2014, 3, 1579-1594. [CrossRef] [PubMed]

52. Stewart, C.A.; Tong, P.; Cardnell, R.J.; Sen, T.; Li, L.; Gay, C.M.; Masrorpour, F.; Fan, Y.; Bara, R.O.; Feng, Y.; et al. Dynamic variations in epithelial-to-mesenchymal transition (EMT), ATM, and SLFN11 govern response to PARP inhibitors and cisplatin in small cell lung cancer. Oncotarget 2017, 8, 28575-28587. [CrossRef] [PubMed]

53. Cardnell, R.J.; Feng, Y.; Diao, L.; Fan, Y.-H.; Masrorpour, F.; Wang, J.; Shen, Y.; Mills, G.B.; Minna, J.D.; Heymach, J.V.; et al. Proteomic markers of DNA repair and PI3K pathway activation predict response to the PARP inhibitor BMN 673 in small cell lung cancer. Clin. Cancer Res. 2013, 19, 6322-6328. [CrossRef] [PubMed]

54. Atrafi, F.; Groen, H.J.M.; Byers, L.A.; Garralda, E.; Lolkema, M.P.; Sangha, R.; Viteri, S.; Chae, Y.K.; Camidge, D.R.; Gabrail, N.; et al. A Phase I Dose-Escalation Study of Veliparib Combined with Carboplatin and Etoposide in Patients with Extensive-Stage Small Cell Lung Cancer and Other Solid Tumors. Clin. Cancer Res. 2018, 25, 496-505. [CrossRef] [PubMed]

55. Owonikoko, T.K.; Dahlberg, S.E.; Sica, G.L.; Wagner, L.I.; Wade, J.L.; Srkalovic, G.; Lash, B.W.; Leach, J.W.; Leal, T.B.; Aggarwal, C.; et al. Randomized Phase II Trial of Cisplatin and Etoposide in Combination with Veliparib or Placebo for Extensive-Stage Small-Cell Lung Cancer: ECOG-ACRIN 2511 Study. J. Clin. Oncol. 2019, 37, 222-229. [CrossRef] [PubMed]

56. De Bono, J.; Ramanathan, R.K.; Mina, L.; Chugh, R.; Glaspy, J.; Rafii, S.; Kaye, S.; Sachdev, J.; Heymach, J.; Smith, D.C.; et al. Phase I, Dose-Escalation, Two-Part Trial of the PARP Inhibitor Talazoparib in Patients with Advanced Germline BRCA1/2 Mutations and Selected Sporadic Cancers. Cancer Discov. 2017, 7, 620-629. [CrossRef] [PubMed]

57. Woll, P.; Gaunt, P.; Steele, N.; Ahmed, S.; Mulatero, C.; Shah, R.; Danson, S.; Hodgkinson, E.; James, K.; Watkins, B.; et al. P1.07-015 STOMP: A UK National Cancer Research Network Randomised, Double Blind, Multicentre Phase II Trial of Olaparib as Maintenance Therapy in SCLC: Topic: Drug Treatment Alone and in Combination with Radiotherapy. J. Thorac. Oncol. 2017, 12, S704-S705. [CrossRef]

58. Lu, S.; Jiang, L.; Ai, X.; Li, J.; Dong, X.; Zhang, D.; Liu, Q. JCSE01.10 A Ph3 Study of Niraparib as Maintenance Therapy in 1L Platinum Responsive Extensive Disease Small Cell Lung Cancer Patients. J. Thorac. Oncol. 2018, 13, S312. [CrossRef]

59. Pietanza, M.C.; Waqar, S.N.; Krug, L.M.; Dowlati, A.; Hann, C.L.; Chiappori, A.; Owonikoko, T.K.; Woo, K.M.; Cardnell, R.J.; Fujimoto, J.; et al. Randomized, Double-Blind, Phase II Study of Temozolomide in Combination with Either Veliparib or Placebo in Patients with Relapsed-Sensitive or Refractory Small-Cell Lung Cancer. J. Clin. Oncol. 2018, 36, 2386-2394. [CrossRef]

60. Farago, A.F.; Drapkin, B.J.; Charles, A.; Yeap, B.Y.; Heist, R.S.; Azzoli, C.G.; Jackman, D.M.; Marcoux, J.P.; Barbie, D.A.; Myers, D.T.; et al. Safety and efficacy of combination olaparib (O) and temozolomide (T) in small cell lung cancer (SCLC). J. Clin. Oncol. 2018, 36, 8571. [CrossRef]

61. Morikawa, N.; Nilsson, M.B.; Guijarro, I.; Fan, Y.-H.; Poteete, A.; Heymach, J.V. Abstract 4847: Evaluation of the combination of olaparib and cediranib in small-cell lung cancer cells. Exp. Mol. Ther. 2018, 78, 4847. 
62. Thomas, A.; Vilimas, R.; Trindade, C.; Erwin-Cohen, R.; Roper, N.; Xi, L.; Krishnasamy, V.; Levy, E.; Mammen, A.; Nichols, S.; et al. Durvalumab in Combination with Olaparib in Patients with Relapsed SCLC: Results from a Phase II Study. J. Thorac. Oncol. 2019, 14, 1447-1457. [CrossRef] [PubMed]

63. Ma, C.X.; Janetka, J.W.; Piwnica-Worms, H. Death by releasing the breaks: CHK1 inhibitors as cancer therapeutics. Trends Mol. Med. 2011, 17, 88-96. [CrossRef] [PubMed]

64. Byers, L.A.; Golden, L.; Zhang, W.; Lin, A.B.; Forster, M. P2.06-028 A Phase 2 Study of Prexasertib in Patients with Extensive Stage Small Cell Lung Cancer: Topic: Mesothelioma and SCLC. J. Thorac. Oncol. 2017, 12, S1088-S1089. [CrossRef]

65. Richer, A.L.; Cala, J.M.; Carson, V.M.; O’Brien, K.; Inge, L.J.; Whitsett, T.G. WEE1 Kinase Inhibitor AZD1775 Has Preclinical Efficacy in LKB1-Deficient Non-Small Cell Lung Cancer. Cancer Res. 2017, 77, 4663-4672. [CrossRef]

66. Matheson, C.J.; Backos, D.S.; Reigan, P. Targeting WEE1 Kinase in Cancer. Trends Pharmacol. Sci. 2016, 37, 872-881. [CrossRef]

67. Van Linden, A.A.; Baturin, D.; Ford, J.B.; Fosmire, S.P.; Gardner, L.; Korch, C.; Reigan, P.; Porter, C.C. Inhibition of Wee1 sensitizes cancer cells to antimetabolite chemotherapeutics in vitro and in vivo, independent of p53 functionality. Mol. Cancer Ther. 2013, 12, 2675-2684. [CrossRef]

68. Lallo, A.; Frese, K.K.; Morrow, C.J.; Sloane, R.S.; Gulati, S.; Schenk, M.W.; Trapani, F.; Simms, N.; Galvin, M.; Brown, S.; et al. The combination of the PARP inhibitor olaparib and the Wee1 inhibitor AZD1775 as a new therapeutic option for small cell lung cancer. Clin. Cancer Res. 2018, 24, 5153-5164. [CrossRef]

69. Leijen, S.; Van Geel, R.M.; Pavlick, A.C.; Tibes, R.; Rosen, L.; Razak, A.R.A.; Lam, R.; DeMuth, T.; Rose, S.; Lee, M.A.; et al. Phase I Study Evaluating WEE1 Inhibitor AZD1775 As Monotherapy and in Combination with Gemcitabine, Cisplatin, or Carboplatin in Patients with Advanced Solid Tumors. J. Clin. Oncol. 2016, 34, 4371-4380. [CrossRef]

70. Hollander, J.D.; Rimpi, S.; Doherty, J.R.; Rudelius, M.; Buck, A.; Hoellein, A.; Kremer, M.; Graf, N.; Scheerer, M.; Hall, M.A.; et al. Aurora kinases A and B are up-regulated by Myc and are essential for maintenance of the malignant state. Blood 2010, 116, 1498-1505. [CrossRef]

71. Lu, Y.; Liu, Y.; Jiang, J.; Xi, Z.; Zhong, N.; Shi, S.; Wang, J.; Wei, X. Knocking down the expression of Aurora-A gene inhibits cell proliferation and induces G2/M phase arrest in human small cell lung cancer cells. Oncol. Rep. 2014, 32, 243-249. [CrossRef] [PubMed]

72. Helfrich, B.A.; Kim, J.; Gao, D.; Chan, D.C.; Zhang, Z.; Tan, A.C.; Bunn, P.A., Jr. Barasertib (AZD1152), a Small Molecule Aurora B Inhibitor, Inhibits the Growth of SCLC Cell Lines In Vitro and In Vivo. Mol. Cancer Ther. 2016, 15, 2314-2322. [CrossRef] [PubMed]

73. Sos, M.L.; Dietlein, F.; Peifer, M.; Schöttle, J.; Balke-Want, H.; Müller, C.; Koker, M.; Richters, A.; Heynck, S.; Malchers, F.; et al. A framework for identification of actionable cancer genome dependencies in small cell lung cancer. Proc. Natl. Acad. Sci. USA 2012, 109, 17034-17039. [CrossRef] [PubMed]

74. Melichar, B.; Adenis, A.; Lockhart, A.C.; Bennouna, J.; Dees, E.C.; Kayaleh, O.; Obermannová, R.; DeMichele, A.; Zatloukal, P.; Zhang, B.; et al. Safety and activity of alisertib, an investigational aurora kinase A inhibitor, in patients with breast cancer, small-cell lung cancer, non-small-cell lung cancer, head and neck squamous-cell carcinoma, and gastro-oesophageal adenocarcinoma: A five-arm phase 2 study. Lancet Oncol. 2015, 16, 395-405. [PubMed]

75. Owonikoko, T.; Nackaerts, K.; Csoszi, T.; Ostoros, G.; Baik, C.; Ullmann, C.D.; Zagadailov, E.; Sheldon-Waniga, E.; Huebner, D.; Leonard, E.J.; et al. OA05.05 Randomized Phase 2 Study: Alisertib (MLN8237) or Placebo + Paclitaxel as Second-Line Therapy for Small-Cell Lung Cancer (SCLC). J. Thorac. Oncol. 2017, 12, S261-S262. [CrossRef]

76. Calvo, E.; Moreno, V.; Flynn, M.; Holgado, E.; Olmedo, M.E.; Criado, M.P.L.; Kahatt, C.; Lopez-Vilariño, J.A.; Siguero, M.; Fernandez-Teruel, C.; et al. Antitumor activity of lurbinectedin (PM01183) and doxorubicin in relapsed small-cell lung cancer: Results from a phase I study. Ann. Oncol. 2017, 28, 2559-2566. [CrossRef]

77. Belgiovine, C.; Bello, E.; Liguori, M.; Craparotta, I.; Mannarino, L.; Paracchini, L.; Beltrame, L.; Marchini, S.; Galmarini, C.M.; Mantovani, A.; et al. Lurbinectedin reduces tumour-associated macrophages and the inflammatory tumour microenvironment in preclinical models. Br. J. Cancer 2017, 117, 628-638. [CrossRef]

78. Paz-Ares, L.G.; Perez, J.M.T.; Besse, B.; Moreno, V.; Lopez, R.; Sala, M.A.; Aix, S.P.; Fernandez, C.M.; Siguero, M.; Kahatt, C.M.; et al. Efficacy and safety profile of lurbinectedin in second-line SCLC patients: Results from a phase II single-agent trial. J. Clin. Oncol. 2019, 37, 8506. 
79. Perez, J.M.T.; Leary, A.; Besse, B.; Castellano, D.E.; Aix, S.P.; Arrondeau, J.; Moreno, V.; Doger, B.; Lopez, R.; Awada, A.; et al. Efficacy and safety of lurbinectedin (PM1183) in small cell lung cancer (SCLC): Results from a phase 2 study. J. Clin. Oncol. 2018, 36, 8570. [CrossRef]

80. Farago, A.F.; Drapkin, B.J.; De Ramos, J.A.L.-V.; Galmarini, C.M.; Núñez, R.; Kahatt, C.; Paz-Ares, L. ATLANTIS: A Phase III study of lurbinectedin/doxorubicin versus topotecan or cyclophosphamide/doxorubicin/vincristine in patients with small-cell lung cancer who have failed one prior platinum-containing line. Futur. Oncol. 2019, 15, 231-239. [CrossRef]

81. Arnold, S.M.; Chansky, K.; Leggas, M.; Thompson, M.A.; Villano, J.L.; Hamm, J.; Sanborn, R.E.; Weiss, G.J.; Chatta, G.; Baggstrom, M.Q. Phase $1 \mathrm{~b}$ trial of proteasome inhibitor carfilzomib with irinotecan in lung cancer and other irinotecan-sensitive malignancies that have progressed on prior therapy (Onyx IST reference number: CAR-IST-553). Investig. New Drugs 2017, 35, 608-615. [CrossRef] [PubMed]

82. Arnold, S.M.; Chansky, K.; Baggstrom, M.Q.; Thompson, M.A.; Sanborn, R.E.; Villano, J.; Waqar, S.N.; Hamm, J.T.; Leggas, M.; Willis, M.; et al. Phase II trial of carfilzomib and irinotecan in relapsed small cell lung cancer (NCT01941316). J. Clin. Oncol. 2019, 37, 8513.

83. Badin, F.B.; Chiang, A.C.; Fisher, W.B.; Orlov, S.; Harper, H.D.; Eskander, E.; Harb, W.A.; Kio, E.; Gopalan, P.K.; Haggstrom, D.E.; et al. Carfilzomib (CFZ), carboplatin and etoposide for previously untreated extensive-stage small cell lung cancer (ES-SCLC): Phase 1b results from a phase 1b/2 study. J. Clin. Oncol. 2016, 34, e20092. [CrossRef]

84. Bruzzese, F.; Rocco, M.; Castelli, S.; Di Gennaro, E.; Desideri, A.; Budillon, A. Synergistic antitumor effect between vorinostat and topotecan in small cell lung cancer cells is mediated by generation of reactive oxygen species and DNA damage-induced apoptosis. Mol. Cancer Ther. 2009, 8, 3075-3087. [CrossRef]

85. Luchenko, V.L.; Salcido, C.D.; Zhang, Y.; Agama, K.; Komlodi-Pasztor, E.; Murphy, R.F.; Giaccone, G.; Pommier, Y.; Bates, S.E.; Varticovski, L. Schedule-dependent synergy of histone deacetylase inhibitors with DNA damaging agents in small cell lung cancer. Cell Cycle 2011, 10, 3119-3128. [CrossRef]

86. Guijarro, I.; Poteete, A.; Ferrarotto, R.; Denning, W.; Hamdi, H.; Roberts, P.; Malik, R.; Bisi, J.; Sorrentino, J.; Strum, J.; et al. P2.03a-048 The CDK4/6 Inhibitor G1T28 Protects Immune Cells from Cisplatin-Induced Toxicity in vivo and Inhibits SCLC Tumor Growth. J. Thorac. Oncol. 2017, 12, S918. [CrossRef]

87. Knudsen, E.S.; Witkiewicz, A.K. The Strange Case of CDK4/6 Inhibitors: Mechanisms, Resistance, and Combination Strategies. Trends Cancer 2017, 3, 39-55. [CrossRef]

88. Hart, L.I.; Andric, Z.G.; Hussein, M.A.; Ferrarotto, R.; Beck, J.T.; Subramanian, J.; Radosavljevic, D.Z.; Jovanovic, D.; Pachipala, K.K.; Samarzija, M.; et al. Effect of trilaciclib, a CDK 4/6 inhibitor, on myelosuppression in patients with previously treated extensive-stage small cell lung cancer receiving topotecan. J. Clin. Oncol. 2019.

89. Jenkinson, S.R.; Williams, J.A.; Jeon, H.; Zhang, J.; Nitta, T.; Ohigashi, I.; Kruhlak, M.; Zuklys, S.; Sharrow, S.; Adams, A.; et al. TRAF3 enforces the requirement for T cell cross-talk in thymic medullary epithelial development. Proc. Natl. Acad. Sci. USA 2013, 110, 21107-21112. [CrossRef]

90. Kazarian, M.; Laird-Offringa, I.A. Small-cell lung cancer-associated autoantibodies: Potential applications to cancer diagnosis, early detection, and therapy. Mol. Cancer 2011, 10, 33. [CrossRef]

91. Reck, M.; Luft, A.; Szczesna, A.; Havel, L.; Kim, S.-W.; Akerley, W.; Pietanza, M.C.; Wu, Y.-L.; Zielinski, C.; Thomas, M.; et al. Phase III Randomized Trial of Ipilimumab Plus Etoposide and Platinum Versus Placebo Plus Etoposide and Platinum in Extensive-Stage Small-Cell Lung Cancer. J. Clin. Oncol. 2016, 34, 3740-3748. [CrossRef] [PubMed]

92. Horn, L.; Reck, M.; Gettinger, S.N.; Spigel, D.R.; Antonia, S.J.; Rupnow, B.A.; Pieters, A.; Selvaggi, G.; Fairchild, J.P.; Peters, S. CheckMate 331: An open-label, randomized phase III trial of nivolumab versus chemotherapy in patients (pts) with relapsed small cell lung cancer (SCLC) after first-line platinum-based chemotherapy (PT-DC). J. Clin. Oncol. 2016, 34, TPS8578. [CrossRef]

93. Antonia, S.J.; López-Martin, J.A.; Bendell, J.; Ott, P.A.; Taylor, M.; Eder, J.P.; Jäger, D.; Pietanza, M.C.; Le, D.T.; De Braud, F.G.M.; et al. Nivolumab alone and nivolumab plus ipilimumab in recurrent small-cell lung cancer (CheckMate 032): A multicentre, open-label, phase 1/2 trial. Lancet Oncol. 2016, 17, 883-895. [CrossRef]

94. Hellmann, M.; Antonia, S.; Ponce, S.; Ott, P.; Calvo, E.; Taylor, M.; Ready, N.; Hann, C.; De Braud, F.; Eder, J.P.; et al. MA09.05 Nivolumab Alone or with Ipilimumab in Recurrent Small Cell Lung Cancer (SCLC): 2-Year Survival and Updated Analyses from the Checkmate 032 Trial. J. Thorac. Oncol. 2017, 12, S393-S394. [CrossRef] 
95. Fischer, R.N.; George, J.; Scheel, A.H.; Schloesser, H.A.; Vehreschild, M.; Brossart, P.; Engel-Riedel, W.; Griesinger, F.; Grohé, C.; Kambartel, K.-O. BIOLUMA: A phase II trial of nivolumab in combination with ipilimumab to evaluate efficacy and safety in lung cancer and to evaluate biomarkers predictive for response-Preliminary results from the SCLC cohort. J. Clin. Oncol. 2019, 37, 8563. [CrossRef]

96. Ready, N.; Owonikoko, T.K.; Postmus, P.E.; Reck, M.; Peters, S.; Pieters, A.; Selvaggi, G.; Fairchild, J.P.; Govindan, R. CheckMate 451: A randomized, double-blind, phase III trial of nivolumab (nivo), nivo plus ipilimumab (ipi), or placebo as maintenance therapy in patients (pts) with extensive-stage disease small cell lung cancer (ED-SCLC) after first-line platinum-based doublet chemotherapy (PT-DC). J. Clin. Oncol. 2016, 34, TPS8579.

97. Ott, P.A.; Elez, E.; Hiret, S.; Kim, D.-W.; Morosky, A.; Saraf, S.; Piperdi, B.; Mehnert, J.M. Pembrolizumab in Patients with Extensive-Stage Small-Cell Lung Cancer: Results from the Phase Ib KEYNOTE-028 Study. J. Clin. Oncol. 2017, 35, 3823-3829. [CrossRef]

98. Chung, H.C.; Lopez-Martin, J.A.; Kao, S.C.-H.; Miller, W.H.; Ros, W.; Gao, B.; Marabelle, A.; Gottfried, M.; Zer, A.; Delord, J.-P.; et al. Phase 2 study of pembrolizumab in advanced small-cell lung cancer (SCLC): KEYNOTE-158. J. Clin. Oncol. 2018, 36, 8506. [CrossRef]

99. Horn, L.; Mansfield, A.S.; Szczęsna, A.; Havel, L.; Krzakowski, M.; Hochmair, M.J.; Huemer, F.; Losonczy, G.; Johnson, M.L.; Nishio, M.; et al. First-Line Atezolizumab plus Chemotherapy in Extensive-Stage Small-Cell Lung Cancer. N. Engl. J. Med. 2018, 379, 2220-2229. [CrossRef]

100. Paz-Ares, Y.L.; Chen, N.; Reinmuth, K.; Hotta, D.; Trukhin, G.; Statsenko, M.J.; Hochmair, M.; Özgüroğlu, J.H.; Ji, O.; Voitko, A.; et al. Overall Survival with Durvalumab Plus Etoposide-Platinum in First-Line Extensive-Stage SCLC: Results from the Caspian Study PL02.11 WCLC. In Proceedings of the World Conference on Lung Cancer, Barcelona, Spain, 7-10 September 2019.

101. Arriola, E.; Wheater, M.; Galea, I.; Cross, N.; Maishman, T.; Hamid, D.; Stanton, L.; Cave, J.; Geldart, T.; Mulatero, C.; et al. Outcome and Biomarker Analysis from a Multicenter Phase 2 Study of Ipilimumab in Combination with Carboplatin and Etoposide as First-Line Therapy for Extensive-Stage SCLC. J. Thorac. Oncol. 2016, 11, 1511-1521. [CrossRef]

102. Gadgeel, S.M.; Pennell, N.A.; Fidler, M.J.; Halmos, B.; Bonomi, P.; Stevenson, J.; Schneider, B.; Sukari, A.; Ventimiglia, J.; Chen, W.; et al. Phase II Study of Maintenance Pembrolizumab in Patients with Extensive-Stage Small Cell Lung Cancer (SCLC). J. Thorac. Oncol. 2018, 13, 1393-1399. [CrossRef] [PubMed]

103. Pujol, J.-L.; Greillier, L.; Audigier-Valette, C.; Moro-Sibilot, D.; Uwer, L.; Hureaux, J.; Guisier, F.; Carmier, D.; Madelaine, J.; Otto, J.; et al. A Randomized Non-Comparative Phase II Study of Anti-Programmed Cell Death-Ligand 1 Atezolizumab or Chemotherapy as Second-Line Therapy in Patients with Small Cell Lung Cancer: Results from the IFCT-1603 Trial. J. Thorac. Oncol. 2019, 14, 903-913. [CrossRef] [PubMed]

104. Cho, D.C.; Mahipal, A.; Dowlati, A.; Chow, W.A.; Segal, N.H.; Chung, K.Y.; Schneider, B.J.; Nemunaitis, J.J.; Razak, A.R.A.; Tsai, F.Y.-C.; et al. Safety and clinical activity of durvalumab in combination with tremelimumab in extensive disease small-cell lung cancer (ED-SCLC). J. Clin. Oncol. 2018, 36, 8517. [CrossRef]

105. Grant, S.C.; Kris, M.G.; Houghton, A.N.; Chapman, P.B. Long survival of patients with small cell lung cancer after adjuvant treatment with the anti-idiotypic antibody BEC2 plus Bacillus Calmette-Guérin. Clin. Cancer Res. 1999, 5, 1319-1323. [PubMed]

106. Giaccone, G.; Debruyne, C.; Felip, E.; Chapman, P.B.; Grant, S.C.; Millward, M.; Thiberville, L.; D'Addario, G.; Coens, C.; Rome, L.S.; et al. Phase III Study of Adjuvant Vaccination with Bec2/Bacille Calmette-Guerin in Responding Patients with Limited-Disease Small-Cell Lung Cancer (European Organisation for Research and Treatment of Cancer 08971-08971B; Silva Study). J. Clin. Oncol. 2005, 23, 6854-6864. [CrossRef] [PubMed]

107. Ponath, P.; Menezes, D.L.; Pan, C.; Chen, B.; Oyasu, M.; Strachan, D.; Leblanc, H.; Sun, H.; Wang, X.-T.; Rangan, V.S.; et al. A Novel, Fully Human Anti-fucosyl-GM1 Antibody Demonstrates Potent In Vitro and In Vivo Antitumor Activity in Preclinical Models of Small Cell Lung Cancer. Clin. Cancer Res. 2018, 24, 5178-5189. [PubMed]

108. Chiappori, A.A.; Soliman, H.; Janssen, W.E.; Antonia, S.J.; Gabrilovich, D.I. INGN-225: A dendritic cell-based p53 vaccine (Ad.p53-DC) in small cell lung cancer: Observed association between immune response and enhanced chemotherapy effect. Expert Opin. Boil. Ther. 2010, 10, 983-991. [CrossRef] 
109. Chiappori, A.A.; Williams, C.C.; Gray, J.E.; Tanvetyanon, T.; Haura, E.B.; Creelan, B.C.; Thapa, R.; Chen, D.T.; Simon, G.R.; Bepler, G.; et al. Randomized-controlled phase II trial of salvage chemotherapy after immunization with a TP53-transfected dendritic cell-based vaccine (Ad.p53-DC) in patients with recurrent small cell lung cancer. Cancer Immunol. Immunother. 2019, 68, 517-527. [CrossRef]

110. Zarogoulidis, K.; Ziogas, E.; Boutsikou, E.; Zarogoulidis, P.; Darwiche, K.; Kontakiotis, T.; Tsakiridis, K.; Porpodis, K.; Latsios, D.; Chatzizisi, O.; et al. Immunomodifiers in combination with conventional chemotherapy in small cell lung cancer: A Phase II, randomized study. Drug Des. Dev. Ther. 2013, 7, 611-617. [CrossRef]

111. Pillai, R.N.; Aisner, J.; Dahlberg, S.E.; Rogers, J.S.; DiPaola, R.S.; Aisner, S.; Ramalingam, S.S.; Schiller, J.H. Interferon alpha plus 13-cis-retinoic acid modulation of BCL-2 plus paclitaxel for recurrent small-cell lung cancer (SCLC): An Eastern Cooperative Oncology Group study (E6501). Cancer Chemother. Pharmacol. 2014, 74, 177-183. [CrossRef]

112. Daniel, V.C.; Marchionni, L.; Hierman, J.S.; Rhodes, J.T.; Devereux, W.L.; Rudin, C.M.; Yung, R.; Parmigiani, G.; Dorsch, M.; Peacock, C.D.; et al. A primary xenograft model of small-cell lung cancer reveals irreversible changes in gene expression imposed by culture in vitro. Cancer Res. 2009, 69, 3364-3373. [CrossRef] [PubMed]

113. Hodgkinson, C.L.; Morrow, C.J.; Li, Y.; Metcalf, R.L.; Rothwell, D.G.; Trapani, F.; Polanski, R.; Burt, D.J.; Simpson, K.L.; Morris, K.; et al. Tumorigenicity and genetic profiling of circulating tumor cells in small-cell lung cancer. Nat. Med. 2014, 20, 897-903. [CrossRef] [PubMed]

114. Normanno, N.; Rossi, A.; Morabito, A.; Signoriello, S.; Bevilacqua, S.; Di Maio, M.; Costanzo, R.; De Luca, A.; Montanino, A.; Gridelli, C.; et al. Prognostic value of circulating tumor cells' reduction in patients with extensive small-cell lung cancer. Lung Cancer 2014, 85, 314-319. [CrossRef] [PubMed]

115. Aggarwal, C.; Wang, X.; Ranganathan, A.; Torigian, D.; Troxel, A.; Evans, T.; Cohen, R.B.; Vaidya, B.; Rao, C.; Connelly, M.; et al. Circulating tumor cells as a predictive biomarker in patients with small cell lung cancer undergoing chemotherapy. Lung Cancer 2017, 112, 118-125. [CrossRef]

116. Igawa, S.; Gohda, K.; Fukui, T.; Ryuge, S.; Otani, S.; Masago, A.; Sato, J.; Murakami, K.; Maki, S.; Katono, K.; et al. Circulating tumor cells as a prognostic factor in patients with small cell lung cancer. Oncol. Lett. 2014, 7, 1469-1473. [CrossRef]

117. Hou, J.-M.; Krebs, M.G.; Lancashire, L.; Sloane, R.S.; Backen, A.; Swain, R.K.; Priest, L.J.; Greystoke, A.; Zhou, C.; Morris, K.; et al. Clinical Significance and Molecular Characteristics of Circulating Tumor Cells and Circulating Tumor Microemboli in Patients with Small-Cell Lung Cancer. J. Clin. Oncol. 2012, 30, 525-532. [CrossRef]

118. Messaritakis, I.; Nikolaou, M.; Politaki, E.; Koinis, F.; Lagoudaki, E.; Koutsopoulos, A.; Georgoulia, N.; Georgoulias, V.; Kotsakis, A. Bcl-2 expression in circulating tumor cells (CTCs) of patients with small cell lung cancer (SCLC) receiving front-line treatment. Lung Cancer 2018, 124, 270-278. [CrossRef]

119. Wang, X.; Ma, K.; Wang, Y.; He, H.; Hu, J.-F.; Li, W. Evaluation of Circulating Tumor Cells in Predicting Therapeutic Response in Small Cell Lung Cancer Patients. Arch. Med Res. 2016, 47, 454-459. [CrossRef]

120. Su, Z.; Wang, Z.; Ni, X.; Duan, J.; Gao, Y.; Zhuo, M.; Li, R.; Zhao, J.; Ma, Q.; Bai, H.; et al. Inferring the Evolution and Progression of Small-Cell Lung Cancer by Single-Cell Sequencing of Circulating Tumor Cells. Clin. Cancer Res. 2019, 25, 5049-5060. [CrossRef]

121. Messaritakis, I.; Politaki, E.; Kotsakis, A.; Dermitzaki, E.-K.; Koinis, F.; Lagoudaki, E.; Koutsopoulos, A.; Kallergi, G.; Souglakos, J.; Georgoulias, V. Phenotypic characterization of circulating tumor cells in the peripheral blood of patients with small cell lung cancer. PLoS ONE 2017, 12, e0181211. [CrossRef]

122. Bettegowda, C.; Sausen, M.; Leary, R.J.; Kinde, I.; Wang, Y.; Agrawal, N.; Bartlett, B.R.; Wang, H.; Luber, B.; Alani, R.M.; et al. Detection of circulating tumor DNA in early- and late-stage human malignancies. Sci. Transl. Med. 2014, 6, 224. [CrossRef] [PubMed]

123. Van Der Drift, M.A.; Hol, B.E.; Klaassen, C.H.; Prinsen, C.F.; Van Aarssen, Y.A.; Donders, R.; Van Der Stappen, J.W.; Dekhuijzen, P.R.; Van Der Heijden, H.F.; Thunnissen, F.B.; et al. Circulating DNA is a non-invasive prognostic factor for survival in non-small cell lung cancer. Lung Cancer 2010, 68, $283-287$. [CrossRef] [PubMed]

124. Sozzi, G.; Roz, L.; Conte, D.; Mariani, L.; Andriani, F.; Vullo, S.L.; Verri, C.; Pastorino, U. Plasma DNA Quantification in Lung Cancer Computed Tomography Screening. Am. J. Respir. Crit. Care Med. 2009, 179, 69-74. [CrossRef] [PubMed] 
125. Almodovar, K.; Iams, W.T.; Meador, C.B.; Zhao, Z.; York, S.; Horn, L.; Yan, Y.; Hernandez, J.; Chen, H.; Shyr, Y.; et al. Longitudinal Cell-Free DNA Analysis in Patients with Small Cell Lung Cancer Reveals Dynamic Insights into Treatment Efficacy and Disease Relapse. J. Thorac. Oncol. 2018, 13, 112-123. [CrossRef]

126. Gardner, E.E.; Lok, B.H.; Schneeberger, V.E.; Desmeules, P.; Miles, L.A.; Arnold, P.K.; Ni, A.; Khodos, I.; De Stanchina, E.; Nguyen, T.; et al. Chemosensitive Relapse in Small Cell Lung Cancer Proceeds through an EZH2-SLFN11 Axis. Cancer Cell 2017, 31, 286-299. [CrossRef]

127. Boumber, Y. Tumor mutational burden (TMB) as a biomarker of response to immunotherapy in small cell lung cancer. J. Thorac. Dis. 2018, 10, 4689-4693. [CrossRef]

128. Ricciuti, B.; Kravets, S.; Dahlberg, S.E.; Umeton, R.; Albayrak, A.; Subegdjo, S.J.; Johnson, B.E.; Nishino, M.; Sholl, L.M.; Awad, M.M. Use of targeted next generation sequencing to characterize tumor mutational burden and efficacy of immune checkpoint inhibition in small cell lung cancer. J. Immunother. Cancer 2019, 7, 87. [CrossRef]

129. Gu, W.; Wang, H.; Li, K.; Wei, G.; Zhang, J.; Zhang, S.; Zhang, L.; Shi, X.; Liu, A. KMT2C mutation associated with tumor mutational burden in small cell lung cancer. J. Clin. Oncol. 2019, 37, e20098.

130. Carvajal-Hausdorf, D.; Altan, M.; Velcheti, V.; Gettinger, S.N.; Herbst, R.S.; Rimm, D.L.; Schalper, K.A. Expression and clinical significance of PD-L1, B7-H3, B7-H4 and TILs in human small cell lung Cancer (SCLC). J. Immunother. Cancer 2019, 7, 65. [CrossRef]

131. Mollaoglu, G.; Guthrie, M.R.; Böhm, S.; Brägelmann, J.; Can, I.; Ballieu, P.M.; Marx, A.; George, J.; Heinen, C.; Chalishazar, M.D.; et al. MYC Drives Progression of Small Cell Lung Cancer to a Variant Neuroendocrine Subtype with Vulnerability to Aurora Kinase Inhibition. Cancer Cell 2017, 31, 270-285. [CrossRef]

132. Xiao, F.; Bai, Y.; Chen, Z.; Li, Y.; Luo, L.; Huang, J.; Yang, J.; Liao, H.; Guo, L. Downregulation of HOXA1 gene affects small cell lung cancer cell survival and chemoresistance under the regulation of miR-100. Eur. J. Cancer 2014, 50, 1541-1554. [CrossRef] [PubMed]

133. Weiskopf, K.; Jahchan, N.S.; Schnorr, P.J.; Cristea, S.; Ring, A.M.; Maute, R.L.; Volkmer, A.K.; Volkmer, J.-P.; Liu, J.; Lim, J.S.; et al. CD47-blocking immunotherapies stimulate macrophage-mediated destruction of small-cell lung cancer. J. Clin. Investig. 2016, 126, 2610-2620. [CrossRef] [PubMed]

(C) 2019 by the authors. Licensee MDPI, Basel, Switzerland. This article is an open access article distributed under the terms and conditions of the Creative Commons Attribution (CC BY) license (http://creativecommons.org/licenses/by/4.0/). 